\title{
Traditional Risk Factors for Stroke in East Asia
}

\author{
Young Dae Kim, ${ }^{\text {a }}$ Yo Han Jung, ${ }^{\text {b }}$ Gustavo Saposnik ${ }^{\mathrm{c}}$ \\ aDepartment of Neurology, Yonsei University College of Medicine, Seoul, Korea \\ bepartment of Neurology, Changwon Fatima Hospital, Changwon, Korea \\ 'Stroke Outcomes Research Unit, Division of Neurology, University of Toronto, Toronto, Canada
}

Stroke is one of the leading causes of death and morbidity worldwide. The occurrence of stroke is strongly dependent on well-known vascular risk factors. After rapid modernization, urbanization, and mechanization, East Asian countries have experienced growth in their aged populations, as well as changes in lifestyle and diet. This phenomenon has increased the prevalence of vascular risk factors among Asian populations, which are susceptible to developing cardiovascular risk factors. However, differing patterns of stroke risk factor profiles have been noted in East Asian countries over the past decades. Even though the prevalence of vascular risk factors has changed, hypertension is still prevalent and the burden of diabetes and hypercholesterolemia will continue to increase. Asia remains a high tobacco-consuming area. Although indicators of awareness and management of vascular risk factors have increased in many East Asian countries, their rates still remain low. Here we review the burdens of traditional risk factors, such as hypertension, diabetes, hypercholesterolemia, and smoking in East Asia. We will also discuss the different associations between these vascular risk factors and stroke in Asian and non-Asian populations.

Keywords Stroke; Epidemiology; Risk factors; Asia

\author{
Correspondence: Young Dae Kim \\ Department of Neurology, Yonsei \\ University College of Medicine \\ 50-1 Yonsei-ro, Seodaemoon-gu, \\ Seoul 03722, Korea \\ Tel.: +82-2-2228-1619 \\ Fax: +82-2-393-0705 \\ E-mail: neuro05@yuhs.ac
}

Received: July 19, 2016

Revised: August 21, 2016

Accepted: August 23, 2016

The authors have no financial conflicts of interest.

\section{Introduction}

Cerebrovascular disease is one of the leading causes of death and morbidity worldwide. ${ }^{1}$ The World Health Organization (WHO) estimates that there were 6.7 million stroke-related deaths in 2012. This comprised $11.9 \%$ of all deaths which was the second highest cause of death worldwide. ${ }^{2}$ While age-standardized stroke mortality has decreased over the past two decades, particularly in high-income countries, the burden of stroke remains high worldwide. Indeed, the absolute number of stroke and stroke-related disability-adjusted life years (DALYs) loss has increased. ${ }^{3,4}$

The burden of cerebrovascular disease in Asia is high. Distinct features, such as a higher burden of stroke than coronary heart disease, as well as a higher incidence of hemorrhagic stroke, have been noted in this region. ${ }^{5}$ In $2002,60 \%$ of the world's to- tal mortality due to stroke occurred in East Asia. ${ }^{6}$ In addition, Asia has a higher burden of vascular risk factors overall. Previously, high-carbohydrate diets with high salt and low fat, economic status, and underlying genetic factors were shown to be possible determinants for the epidemic of vascular risk factors in Asian countries. ${ }^{5,7-11}$ Following rapid modernization, urbanization, and mechanization, East Asian countries have experienced growth in their aged populations, as well as changes in lifestyle and diet. Together, these changes have exacerbated vascular risk factor profiles in Asian populations. ${ }^{12-15}$ As a result, the prevalence of vascular risk factors and their impact on cardiovascular disease has changed along with the varying patterns seen in each country. ${ }^{5,16}$

The objective of this article was to review the burden of traditional vascular risk factors and changes in these burdens over several decades in Asian countries. Because there is considerable 
heterogeneity in ethnicity, as well as epidemiologic differences in Asia, ${ }^{17}$ we mainly focused on data from five East Asian countries: China, Japan, the Republic of Korea, Mongolia, and Taiwan. We concentrated our efforts on four risk factors carrying a high population attributable risk for stroke or stroke-related DALYs. These risk factors were hypertension, diabetes, hypercholesterolemia, and smoking (Tables 1 and 2). These factors are also recognized

Table 1. Population-attributable risks of ischemic stroke ${ }^{88}$

\begin{tabular}{|c|c|c|}
\hline Risk factors & \multicolumn{2}{|c|}{ Population-attributable risk } \\
\hline \multicolumn{3}{|l|}{ Hypertension } \\
\hline Age (year) & Men & Women \\
\hline $20-34$ & 99 & 98 \\
\hline $35-44$ & 99 & 106 \\
\hline $45-54$ & 100 & 103 \\
\hline $55-64$ & 100 & 102 \\
\hline $65-74$ & 100 & 101 \\
\hline $75+$ & 100 & 101 \\
\hline Diabetes & \multicolumn{2}{|c|}{$27-5$} \\
\hline High total cholesterol & \multicolumn{2}{|c|}{$9.1(5.7-13.8)$} \\
\hline Cigarette smoking & \multicolumn{2}{|c|}{$14-12^{*}$} \\
\hline
\end{tabular}

*This value is for stroke deaths, not ischemic stroke incidence. as major culprits of atherosclerotic stroke in the Asia Pacific Cohort Studies Collaboration (APCSC), a collaborative project that pooled data regarding cardiovascular disease in the Asia Pacific region from 44 existing longitudinal cohort studies. In addition to data from nationwide studies in each country, we also investigated trends in the burden of risk factors using the published data on estimated trends between 1990 and 2008. These data included mean systolic blood pressure, ${ }^{18}$ fasting blood glucose, ${ }^{19}$ serum total cholesterol ${ }_{1}^{20}$ and prevalence of daily smoking. ${ }^{21}$ All

Table 2. Population-attributable fractions of stroke-related disabilityadjusted life-years ${ }^{72}$

\begin{tabular}{lcccc}
\hline Country & $\begin{array}{c}\text { High systolic } \\
\text { blood } \\
\text { pressure }\end{array}$ & $\begin{array}{c}\text { High fasting } \\
\text { plasma } \\
\text { glucose }\end{array}$ & $\begin{array}{c}\text { High total } \\
\text { cholesterol }\end{array}$ & Smoking \\
\hline China & 72.9 & 11.7 & 2.3 & 25 \\
Japan & 51.5 & 9.2 & 3.8 & 17.3 \\
Mongolia & 76.2 & 14 & 2.3 & 29.2 \\
Republic of Korea & 53.4 & 10.2 & 4.6 & 20.2 \\
Taiwan & 58.8 & 10.3 & 4.1 & 21.3 \\
United Kingdom & 47.7 & 9.4 & 5.4 & 14.7 \\
United States & 47.8 & 14.2 & 7.1 & 16.4 \\
\hline
\end{tabular}

Table 3. Data sources and standardization methods used in previous studies estimating the trends of risk factors

\begin{tabular}{|c|c|c|}
\hline Data & Data sources used for estimation & Standardization method \\
\hline Mean systolic blood pressure ${ }^{18}$ & $\begin{array}{l}\text { Data from published and unpublished health examination surveys and epidemiological } \\
\text { studies (786 country-years and } 5.4 \text { million participants) }\end{array}$ & \multirow{5}{*}{$\begin{array}{l}\text { Age-standardized to the WHO } \\
\text { reference population. }\end{array}$} \\
\hline Mean fasting plasma glucose ${ }^{19}$ & $\begin{array}{l}\text { Data from published and unpublished health examination surveys and epidemiological } \\
\text { studies ( } 370 \text { country-years and } 2.7 \text { million participants) }\end{array}$ & \\
\hline Mean serum total cholesterol ${ }^{20}$ & $\begin{array}{l}\text { Data from published and unpublished health examination surveys and epidemiological } \\
\text { studies ( } 321 \text { country-years and } 3.0 \text { million participants) }\end{array}$ & \\
\hline Smoking prevalence ${ }^{21}$ & $\begin{array}{l}\text { Data from major multicountry survey programs, national multiyear survey programs, } \\
\text { and } 3 \text { large databases (the WHO Global Infobase, the International Smoking Statis- } \\
\text { tics, and the Global Health Data Exchange) }(2,102 \text { country-years of data for a total } \\
\text { of } 38,315 \text { country-year-age-sex data points from } 181 \text { countries) }\end{array}$ & \\
\hline Stroke incidence $e^{4,65}$ & Data from the Global Burden of Diseases, Injuries, and Risk Factors study 2010 & \\
\hline
\end{tabular}

WHO, World Health Organization.

Table 4. Commonly used definitions for traditional vascular risk factors

\begin{tabular}{|c|c|}
\hline Risk factors & Definition \\
\hline Hypertension & $\begin{array}{l}\text { Systolic blood pressure } \geq 140 \mathrm{mmhg} \\
\text { and/or diastolic blood pressure } \geq 90 \mathrm{mmhg} \\
\text { or use of anti-hypertensive medication }\end{array}$ \\
\hline Diabetes mellitus & $\begin{array}{l}\text { Fasting glucose level } \geq 7 \mathrm{mmol} / \mathrm{L}(126 \mathrm{mg} / \mathrm{dL}) \\
\text { or A1c } \geq 6.5 \% \\
\text { or } 2 \text {-hour plasma glucose in one } 75-\mathrm{g} \text { oral glucose tolerance test } \geq 11.1 \mathrm{mmol} / \mathrm{L}(200 \mathrm{mg} / \mathrm{dL}) \\
\text { or random plasma glucose } \geq 11.1 \mathrm{mmol} / \mathrm{L}(200 \mathrm{mg} / \mathrm{dL})\end{array}$ \\
\hline Hypercholesterolemia & $\begin{array}{l}\text { Fasting total cholesterol } \geq 6.2 \mathrm{mmol} / \mathrm{L}(240 \mathrm{mg} / \mathrm{dL}) \\
\text { or taking cholesterol lowering medication } \\
\text { or serum high-density lipoprotein-cholesterol }<1 \mathrm{mmol} / \mathrm{L}(40 \mathrm{mg} / \mathrm{dL}) \\
\text { or serum triglyceride } \geq 2.3 \mathrm{mmol} / \mathrm{L}(200 \mathrm{mg} / \mathrm{dL}) \\
\text { or serum low-density lipoprotein-cholesterol } \geq 4.1 \mathrm{mmol} / \mathrm{L}(160 \mathrm{mg} / \mathrm{dL})\end{array}$ \\
\hline Current smoker & $\begin{array}{l}\text { Currently smokes either every day or some days ( } \pm \text { within } 1, \text { or } 3, \text { or } 6 \text { months) } \\
\text { or smoked greater than } 100 \text { cigarettes in a lifetime and now smokes every day or some days }\end{array}$ \\
\hline
\end{tabular}


these estimated data were systematically standardized and validated, which enabled us to compare the burden of risk factors across countries (Table 3 ).

There are diagnostic criteria for these risk factors that have been used in other clinical reports (Table 4). In this study, the definitions of risk factors were as follows: hypertension was defined as having a systolic blood pressure of $\geq 140 \mathrm{mmHg}$, and/or a diastolic blood pressure of $\geq 90 \mathrm{mmHg}$, and/or use of antihypertensive agents; diabetes was defined as having a fasting glucose level of $\geq 7 \mathrm{mmol} / \mathrm{L}$ (126 mg/dL) or taking hypoglycemic agents; hypercholesterolemia was defined as having a total cholesterol level of $\geq 6.2 \mathrm{mmol} / \mathrm{L}(240 \mathrm{mg} / \mathrm{dL})$. However, because there are wide variations in the definition of hypercholesterolemia between studies, we mainly used total cholesterol levels for this review.

\section{Burdens of traditional risk factors for stroke in East Asia}

\section{Elevated blood pressure and prevalence of hypertension}

Previously, populations in many East Asian countries, except Japan, were reported to have a lower prevalence of hypertension or mean systolic blood pressure lower than or similar to that of Western countries. ${ }^{22-24}$ Analyses of reports published between 1980 and the early 2000s indicated that the age-standardized prevalence of hypertension ranged between 19\% and 28\% in East Asian countries (China, the Republic of Korea, and Taiwan), while Japan had a higher prevalence of hypertension (38.3\%). ${ }^{22,24}$ The age-standardized average systolic blood pressure in the Western Pacific region, which included China, the Republic of Korea, and Taiwan, had the lowest average (124 mmHg) among the 14 world regions defined by the $\mathrm{WHO} .^{23}$

However, the prevalence of hypertension has notably changed in different manners among East Asian countries. In Japan, there has been a decrease in mean systolic blood pressure in all age groups, as well as in both men and women since around $1965 .^{25,26}$ Likewise, the prevalence of hypertension decreased in almost all age groups, except men aged $>50$ years. ${ }^{26}$ In the Republic of Korea, a national survey indicated that the age-adjusted prevalence of hypertension decreased from 29.9\% in 1998 to $25.5 \%$ in 2014 , although the prevalence fluctuated to some extent, with a slight increase to $29.0 \%$ between 2007 and 2012. ${ }^{27}$ In Taiwan, nationwide surveys such as the Nutrition and Health Survey in Taiwan (NAHSIT), which was carried out between 1993 and 1996, and the Taiwanese Survey on Hypertension, Hyperglycemia, and Hyperlipidemia (TwSHHH), which was carried out in 2002, revealed that the age-standardized prevalence of hypertension decreased from $26.8 \%$ in NAHSIT (1993-1996) to 23.5\% in TwSHHH (2002). ${ }^{28}$ Unlike Japan, the Republic of Korea, and Taiwan, China seemed to experience a rise in the prevalence of hypertension. In China, the age-standardized prevalence of hypertension was $11.3 \%$ in 1991, $18.0 \%$ in 2002 , and $26.6 \%$ in 2007-2008. ${ }^{29-31}$ In Mongolia, two nationwide cross-sectional surveys conducted by STEPS (STEPwise Approach to Surveillance) indicated that the prevalence of hypertension was similar in $2005(28.1 \%)$ and $2009(27.3 \%))^{32,33}$ Figure 1 shows that the mean systolic blood pressure has increased since 1990 in China and Mongolia, while there was a decreasing trend for systolic blood pressure in other countries.

Within the East Asian population, blood pressure and the prevalence of hypertension has been reported to be higher in older aged men, those with high salt consumption, and popula-

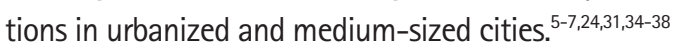

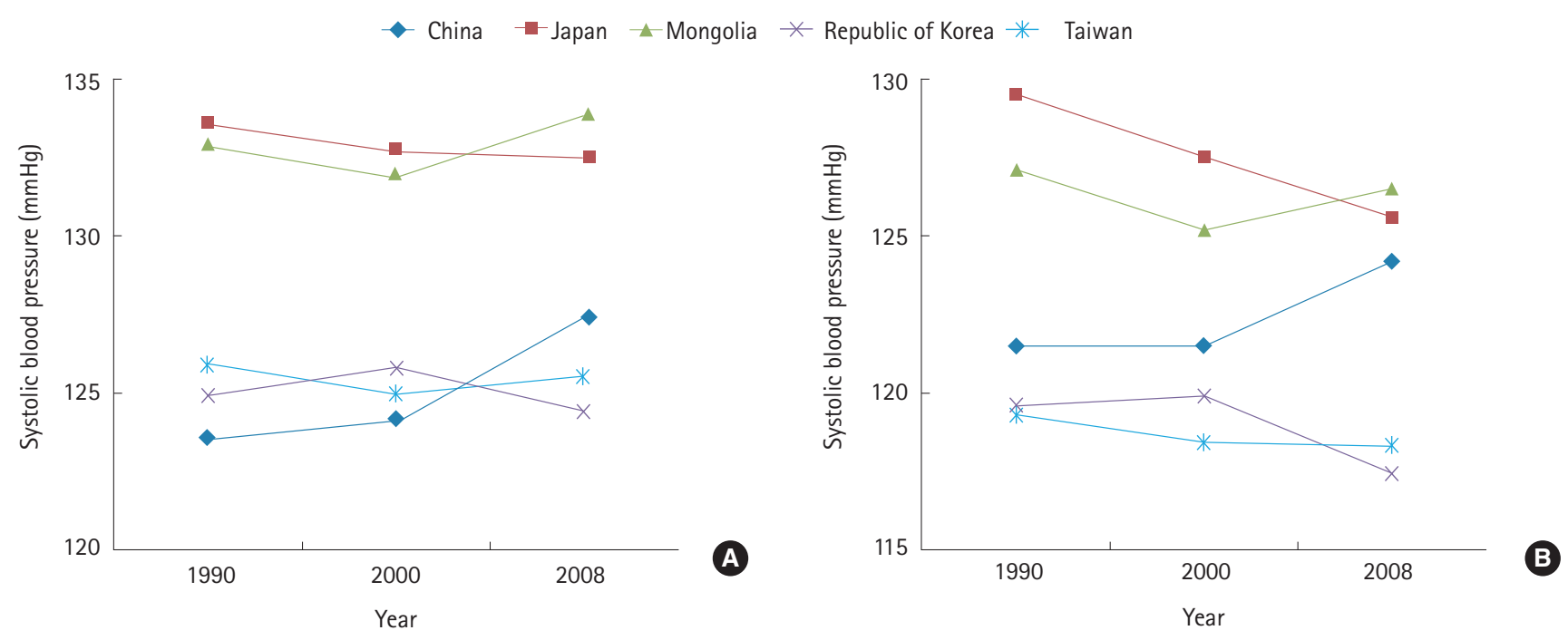

Figure 1. Trends in age-standardized mean systolic blood pressure $(\mathrm{mmHg})$ for men $(\mathrm{A})$ and women $(B)$. 


\section{Diabetes}

Globally, the number of diabetic adults has more than doubled over the last 30 years..$^{19}$ In Asia, the pattern of increasing diabetes prevalence has been different from that found in other regions in that the increase has occurred over a much shorter time period. For example, the prevalence of diabetes in the United States has doubled over the past 40 years, ${ }_{1}^{39}$ while the prevalence of diabetes in many Asian countries has increased 3-5-fold during the past 30 years. ${ }^{13}$ In China, the prevalence of diabetes has increased rapidly from 1\% in 1980 to $9.7 \%$ in 2007-2008, and to $11.6 \%$ (including cases with $\mathrm{HbA1c} \geq 6.5$ ) in 2010 . ${ }^{40,41}$ Japan and the Republic of Korea have also experienced marked increases in the prevalence of diabetes. ${ }^{15,19,37}$ Likewise, the prevalence of diabetes has increased in Taiwan (3.15\% in 2000 to $4.22 \%$ in 2008) ${ }^{42}$ and in Mongolia (2.9\% in 1999 to $6.5 \%$ in 2009). 32,43

Global estimates of diabetes prevalence for 2013, provided by the International Diabetes Federation, showed that the prevalence of diabetes in East Asian countries (5.1\% in Japan, 9.0\% in China, 7.5\% in the Republic of Korea, 8.3\% in Taiwan) was similar to that in the United States (9.2\%) and Canada (7.9\%), and higher than that in the United Kingdom (4.9\%). In fact, more than $40 \%$ of diabetic patients globally live in East Asia. ${ }^{44}$ Mean fasting glucose has increased in China, Japan, and Mongolia, and decreased in the Republic of Korea and Taiwan between 1990 and 2008 (Figure 2).

The prevalence of diabetes and impaired glucose tolerance is expected to further increase in Asia at a rapid rate. ${ }^{44}$ Because Asians have a greater risk of diabetes, even at earlier ages and lower BMI levels, ${ }^{12,13,15,45}$ rapid socioeconomic development, increases in westernized diet, and changes in lifestyle can aggra- vate this phenomenon. Diabetes in East Asia was also related to older age, obesity, smoking, urban living, living in economically developed regions, and a family history of diabetes. ${ }^{41,46}$

\section{Hypercholesterolemia}

East Asian populations had generally lower levels of serum total cholesterol than those of Western countries. ${ }^{5}$ Available reports indicate that Japan was one of the countries with the lowest values of total cholesterol in the world. However, total cholesterol levels in the Japanese population increased dramatically between 1958 and $1986 .{ }^{47}$ The Republic of Korea and China also had increased mean total cholesterol levels in the 1970s and $1990{ }^{48}$ During this period, the incidence of ischemic heart disease in this region was reported to increase along with increased total cholesterol levels. ${ }^{49-51}$

Although the trends for increased total cholesterol levels in East Asian adults and children prevail, mean age-standardized total cholesterol levels are still lower in most East Asian countries than in Western countries, including the United States and the United Kingdom. ${ }^{20}$ However, in Japan, total cholesterol levels in males and females have increased by $0.13-0.15 \mathrm{mmol} / \mathrm{L}$ per decade, which has resulted in higher total cholesterol levels than those in the United States and Canada. In fact, total cholesterol levels in the Japanese population have approached levels found in Western Europe. ${ }^{20}$ Figure 3 shows that there was a rise in serum total cholesterol levels in Japan, China, and the Republic of Korea. However, decreasing trends for serum total cholesterol levels were noted in Mongolia and Taiwan, although previous reports suggest that there is a trend for an increase in dyslipidemia in these two countries. ${ }^{52,53}$

These trends for increasing total cholesterol levels in many

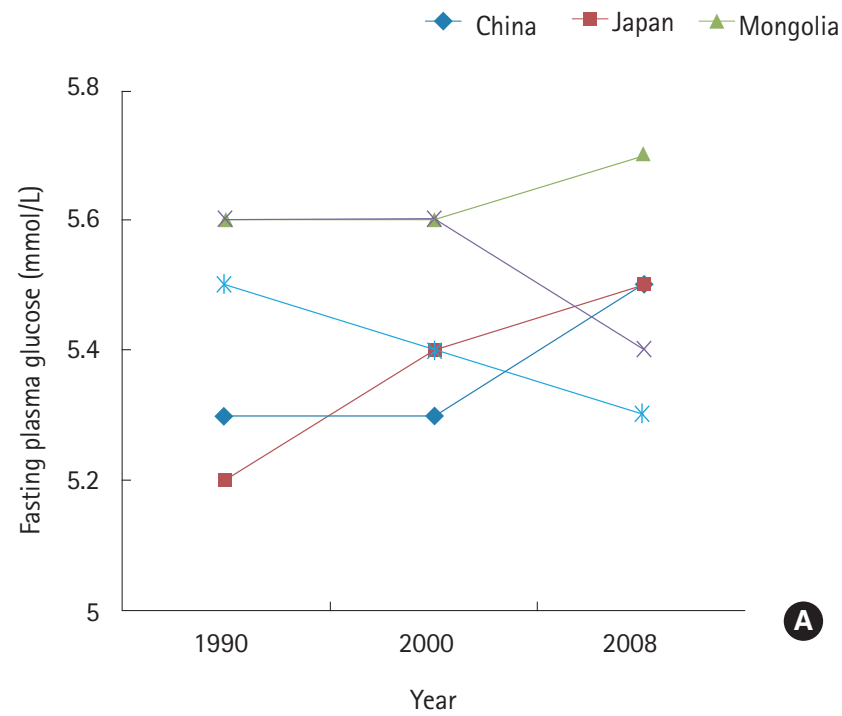

$*$ Republic of Korea $* \quad$ Taiwan

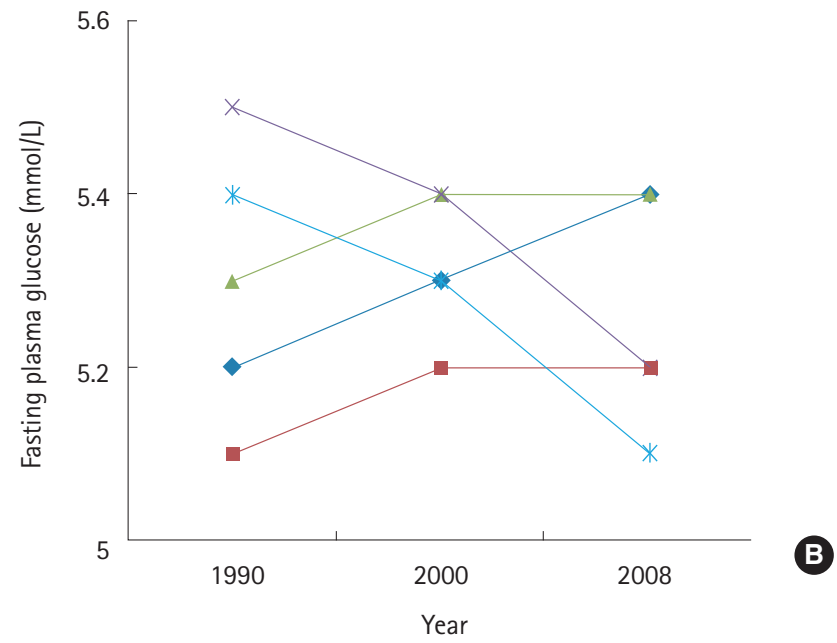

Figure 2. Trends in age-standardized mean fasting blood glucose ( $\mathrm{mmol} / \mathrm{L})$ for men $(A)$ and women (B). 
East Asian countries were associated with increasingly older populations, changes in dietary patterns, and rapid urbanization. ${ }^{32,33,54}$ As mentioned earlier, because of the epidemic transition over the past decades in East Asia, westernized diet patterns of total and saturated fat consumption, foods from animal sources, and processed foods, together with low levels of physical activity, have become more common. ${ }^{20,55,56}$ The incidence of obesity has also increased over the past decades, even among Asian young adults and children. ${ }^{57-60}$ These changes have played a role in the increase in average cholesterol levels in East Asia.

\section{Smoking}

Asia is the world's largest tobacco consuming region, with seven Asian countries in the top ten countries ranked as having the highest tobacco consumption levels. China was ranked num- ber one with 301 million current smokers, which composed $28.1 \%$ of adults in 2010. ${ }^{61}$ Other countries in East Asia also had similar rates of current smokers (the Republic of Korea [24.2\% in $2014]^{27}$ and Mongolia [27.7\% in 2009] ${ }^{32}$ ).

Historically, there has been an imbalance in smoking prevalence between men and women in East Asia. Approximately 40$50 \%$ of men in East Asia are current smokers, which is a proportion higher than those found in the United States and the United Kingdom. ${ }^{5,62}$ The prevalence of smoking (current or former smokers) reaches 70-80\% among men aged 50-59 in China, Japan, and the Republic of Korea. ${ }^{62}$ However, the prevalence of smoking in women is low. Thus, the ratios of prevalence between male and female smokers is about 22:1 in China, ${ }_{1}{ }^{1} 3: 1$ in Japan, ${ }_{1}^{37}$ 7:1 in the Republic of Korea, ${ }^{36}$ and 7:1 in Mongolia. ${ }^{32}$

In China, Japan, the Republic of Korea, and Taiwan, the preva-
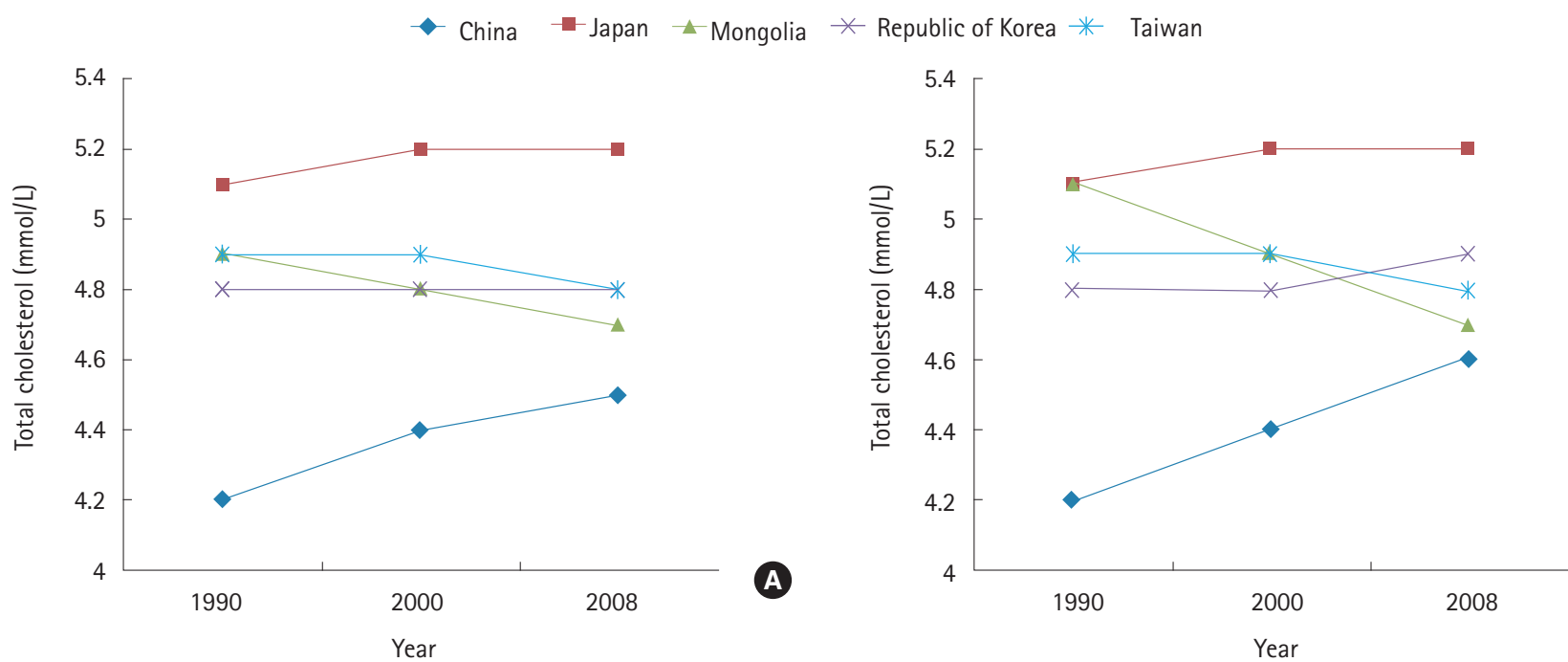

B

Figure 3. Trends in age-standardized mean total cholesterol (mmol/L) for men (A) and women (B).
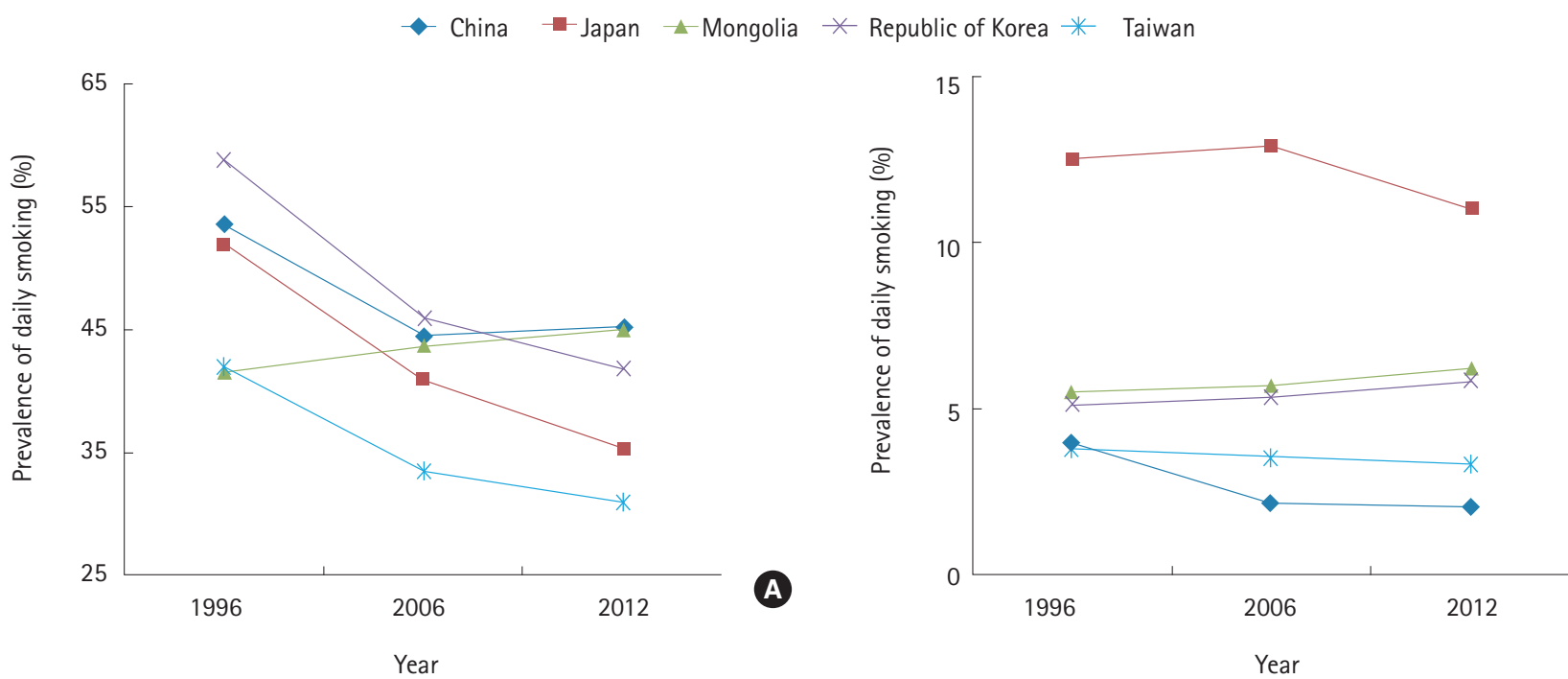

B

Figure 4. Trends in age-standardized prevalence (\%) of daily tobacco smoking for men (A) and women (B). 
lence of current smoking in men has decreased over the past decades, $_{1}^{37,63}$ although it is still high. In contrast, the prevalence of current smoking has increased in Mongolia (Figure 4). ${ }^{52}$ Moreover, there seems to be an increase in smoking among women and younger aged groups in some East Asian countries, such as China ${ }_{1}^{64}$ the Republic of Korea, ${ }^{27}$ and Mongolia. ${ }^{32,33}$

\section{Impact of vascular risk factors on stroke among Asian populations}

\section{Trends of stroke incidence in East Asian countries}

To compare stroke incidence between countries, we extracted data regarding stroke incidence in 5 countries from the Global Burden of Diseases, Injuries, and Risk factors study (GBD 2010) (Table 3). ${ }^{4,65}$ Data from the United States and the United Kingdom were also used for comparison. In 1990, age-standardized stroke incidences (per 100,000 person-years) in East Asian countries were 247.53-347.78, which was higher than those found in the United States (220.66) and the United Kingdom (141.97). Since 1990, stroke (either ischemic or hemorrhagic) incidence has increased in China, Mongolia, and Taiwan, while there was a decrease in stroke incidence in Japan and the Republic of Korea (Figure 5). In Taiwan, the increase in total stroke incidence was due to an increase in hemorrhagic stroke incidence. In 2010, all East Asian countries, except for the Republic of Korea, still had higher stroke incidences compared to the United States and the United Kingdom (Figure 5).

\section{Relationships between risk factors and stroke incidence in East Asia}

As shown earlier, in China and Mongolia, there was an increase in stroke incidence between 1990 and 2010, along with an increase in mean systolic blood pressure and the prevalence of hypertension. In contrast, there were decreases in stroke incidence in Japan and the Republic of Korea, with decreasing mean systolic blood pressures and a decreasing prevalence of hypertension. High blood pressure had the highest effect on stroke in the East Asia and Pacific region, with population-attributable fractions of 50\% of stroke mortality. ${ }^{37}$ Elevated systolic blood pressure had a stronger relationship with stroke (in particular, hemorrhagic stroke) in Asians than in non-Asian populations. ${ }^{66-70}$ A recent meta-analysis using population-based cohort studies of

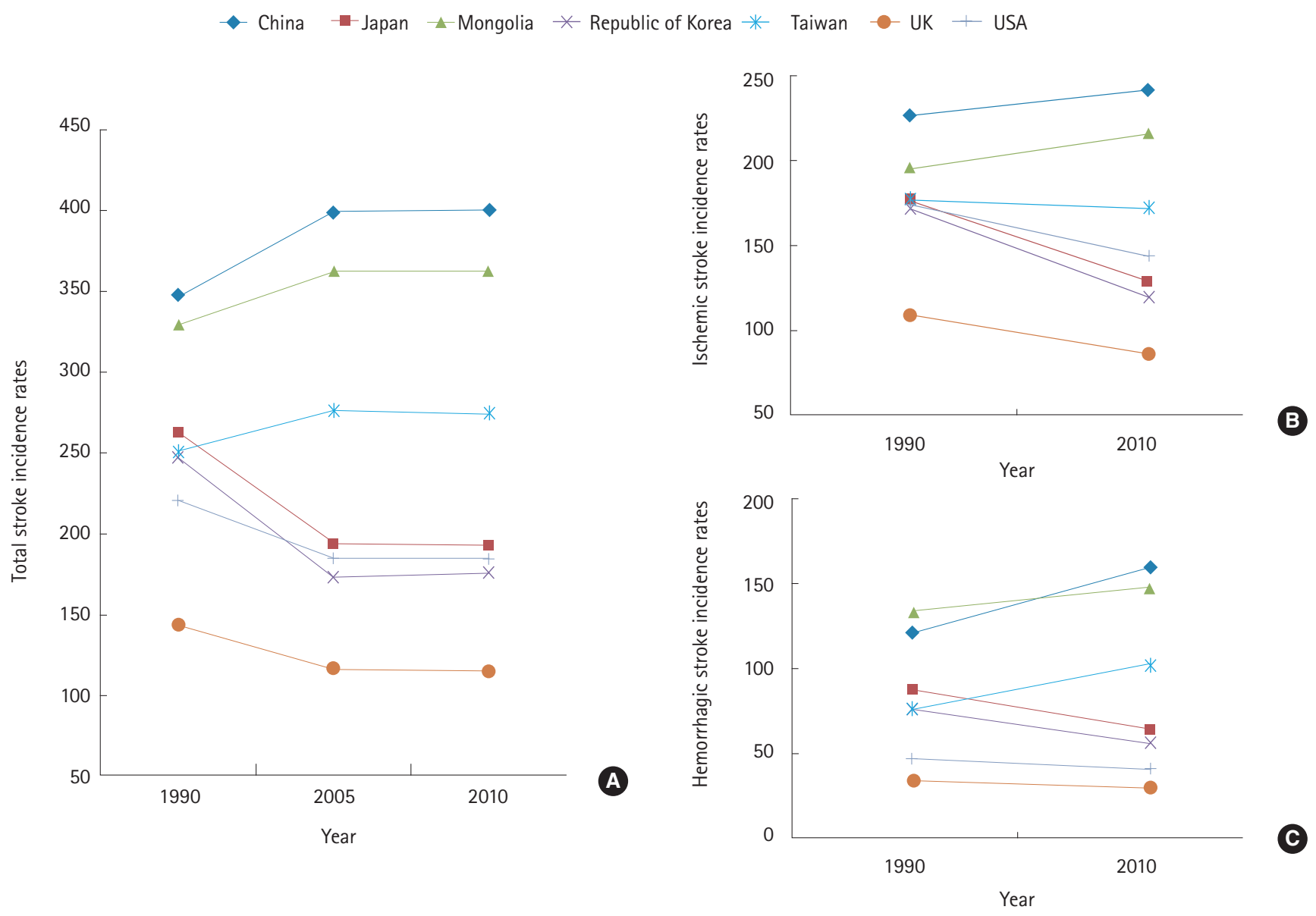

Figure 5. Trends in age-standardized incidence rate (per 100,000 people) of total stroke (A), ischemic stroke (B), and hemorrhagic stroke (C). 
11 Western countries and 11 Asian countries (mainly China, Japan, and the Republic of Korea), also demonstrated that the risk of stroke associated with elevated blood pressure was greater among Asians than Western populations. This is indicated by the fact that the hazard ratio (HR) for systolic blood pressure $\geq 140$ $\mathrm{mmHg}$ and the presence of hypertension were 6.22 and 2.84 , respectively, in Asians, compared to 2.39 and 1.79 in Western populations. ${ }^{71}$ The Global Burden of Disease Study 2013 indicated that high systolic blood pressure had the largest effect on the burden of stroke in East Asian countries, accounting for a population-attributable fraction of $52-73 \%$ of stroke-related DALYs. This is higher than the burden reported in the United Kingdom (48\%) and the United States (48\%) (Table 2). ${ }^{72}$ Recently, the INTERSTROKE study also showed that the population-attributable risk of stroke due to hypertension was higher in Asian populations than in those of other ethnicities or regions. ${ }^{73}$ These results

Table 5. Awareness, treatment, and control rate (\%) of risk factors over the decades

\begin{tabular}{|c|c|c|c|c|c|c|}
\hline Risk factor & Item & China & Japan & Mongolia & Republic of Korea & Taiwan \\
\hline \multirow[t]{3}{*}{ Hypertension } & Awareness & $\begin{array}{l}44.7 \text { in } 2000-2001_{1}^{38} \\
24 \text { in } 2002_{1}^{30} \\
45 \text { in } 2007-2008^{31}\end{array}$ & $\begin{array}{l}54 \text { in 2000, } \\
65.7 \text { in men and } 72.7 \text { in } \\
\text { women in } 2000-2001^{90}\end{array}$ & & $\begin{array}{l}33.5 \text { in 2001, } \\
63.2 \text { in 2010-2012 }\end{array}$ & $\begin{array}{l}22-22.5 \text { in men and } 39-39.3 \\
\text { in women in } 1993-19966^{28,91} \\
55.8 \text { in men and } 73.6 \text { in } \\
\text { women in } 2002^{28}\end{array}$ \\
\hline & Treatment & $\begin{array}{l}28.2 \text { in } 2000-2001_{1}^{38} \\
20 \text { in } 2002_{1}^{30} \\
36.2 \text { in } 2007-2008^{31}\end{array}$ & $\begin{array}{l}46.1 \text { in } 2000{ }^{92} \\
33.2-53.5 \text { in men and } \\
34.3-62 \text { in women in } \\
2000,{ }^{26} \\
16.4-61.1 \text { in men and } \\
33.3-57.1 \text { in women in } \\
2000-2001,{ }^{90} \\
54.4 \text { in } 2008^{89} \\
29.6 \text { in } 2009^{93} \\
43.4-64.6 \text { in men and } \\
31.2-68.8 \text { in women in } \\
2010^{26}\end{array}$ & $\begin{array}{l}74.2 \text { in } 2006^{33} \\
38.9 \text { in } 2009^{32}\end{array}$ & $\begin{array}{l}31.9 \text { in } 2001 \\
57.6 \text { in } 2010-2012^{27}\end{array}$ & $\begin{array}{l}13-13.4 \text { in men and } 27.6-28 \\
\text { in women in } 1993-1996,{ }^{28,91} \\
44.3 \text { in men and } 59.4 \text { in } \\
\text { women in } 2002^{28}\end{array}$ \\
\hline & Control & $\begin{array}{l}8.1 \text { in } 2000-2001_{1}^{38} \\
5 \text { in } 2002_{1}^{30} \\
11.1 \text { in } 2007-2008^{31}\end{array}$ & $\begin{array}{l}15.2-23.4 \text { in men and } \\
21.6-27.8 \text { in women in } \\
200,^{26} \\
11.9 \text { or } 41.5 \text { in } 2000_{1}^{89,92} \\
27 \text { in } 2008_{1}^{89} \\
23.7 \text { or } 24.8 \text { in } 2009_{1}^{89,93} \\
29.9-33.3 \text { in men and } \\
40.5-44.1 \text { in women in } \\
2010^{26}\end{array}$ & 13.3 in $2009^{32}$ & $\begin{array}{l}12.1 \text { in } 2001 \\
40.5 \text { in } 2010-2012^{27}\end{array}$ & $\begin{array}{l}2-2.4 \text { in men and 5-5.1 in } \\
\text { women in } 1993-19966^{28,91} \\
21 \text { in men and } 28.5 \text { in } \\
\text { women in } 2002^{28}\end{array}$ \\
\hline \multirow[t]{3}{*}{ Diabetes } & Awareness & $\begin{array}{l}23.7 \text { in } 2000-2001^{94} \\
30.1 \text { in } 2010^{82}\end{array}$ & & & 71.3 in $2010-2012^{27}$ & $\begin{array}{l}70 \text { in men and } 63 \text { in women } \\
\text { in } 1993-1996^{95}\end{array}$ \\
\hline & Treatment & $\begin{array}{l}20.3 \text { in } 2000-2001,{ }^{94} \\
25.8 \text { in } 2010^{82}\end{array}$ & & $\begin{array}{l}37.4 \% \text { with drugs, } \\
13.7 \% \text { with insulin } \\
\text { in } 2006 \text {, }^{33} \\
16.7 \% \text { with drugs, } \\
9.9 \% \text { with insulin in } \\
2009^{32}\end{array}$ & 62.3 in $2010-2012^{27}$ & \\
\hline & Control & $\begin{array}{l}8.3 \text { in 2000-2001, } \\
39.7 \text { (among patients } \\
\text { treated) in } 2010^{82}\end{array}$ & $\begin{array}{l}34 \text { in } 2000-2002^{96} \\
36.2-43.1 \text { in } 2006-2008^{97}\end{array}$ & & 28.2 in $2010-2012^{27}$ & $\begin{array}{l}27 \text { in } 1998,{ }^{98} \\
11.2 \text { (among patients with } \\
\text { insulin therapy) in } 2005- \\
2006^{99} \\
11.7 \text { (among patients with } \\
\text { insulin therapy) in } 2010- \\
2012^{100}\end{array}$ \\
\hline \multirow[t]{3}{*}{$\begin{array}{l}\text { Hypercholeste- } \\
\text { rolemia }\end{array}$} & Awareness & 24.4 in $2003-2013^{101}$ & $\begin{array}{l}55.7 \text { in men and } 58.6 \text { in } \\
\text { women in } 2000-2001^{90}\end{array}$ & & 45.2 in $2010-2012^{27}$ & \\
\hline & Treatment & 8.8 in $2003-2013^{101}$ & $\begin{array}{l}13.3-52.2 \text { in men and } \\
16.7-52.5 \text { in women in } \\
2000-2001,{ }^{90}\end{array}$ & & 35 in $2010-2012^{27}$ & \\
\hline & Control & 4.3 in $2003-2013^{101}$ & $\begin{array}{l}72.3 \text { ( } 44.5 \text { for secondary } \\
\text { prevention) in } 2009^{102}\end{array}$ & & 28.1 in $2010-2012^{27}$ & $\begin{array}{l}64.9 \text { in } 2002-2003{ }^{103} \\
65.9 \text { (among patients with } \\
\text { lipid lowering therapy) in } \\
2006-2007^{104}\end{array}$ \\
\hline
\end{tabular}


imply that stroke or stroke burden can be effectively prevented by better hypertension management in Asia. In fact, improvements in hypertension control were related to decreases in systolic blood pressure and the risk of stroke or stroke burden in Japan and the Republic of Korea. Although the impact of hypertension on stroke has declined during the past several decades owing to improved management of hypertension, hypertension is still the strongest risk factor for stroke in East Asia. ${ }^{74,75}$

The trends for diabetes or hypercholesterolemia have not always been comparable to changes in stroke incidence in different countries. This may be due to relatively smaller effects of diabetes or hypercholesterolemia compared to hypertension on the incidence of stroke. However, as the impact of hypertension on stroke occurrence decreases, the contributions of diabetes or hypercholesterolemia will become greater. In fact, in Japan, a rapid increase in the prevalence of metabolic disorders such as glucose intolerance, hypercholesterolemia, and obesity, has offset the impacts of improvements in hypertension control on stroke occurrence. ${ }^{74}$ Furthermore, considering that many Asian countries have experienced increasing burdens of atherosclerosis in intraand extra-cranial cerebral arterial beds, which can be affected by hypercholesterolemia and metabolic syndrome, ${ }^{76-80}$ the increasing trends for diabetes and hypercholesterolemia may have greater effects on stroke risk in the future.

\section{Awareness, treatment, and control rates of risk factors}

Table 5 summarizes previous reports regarding awareness, treatment, and control rates of traditional risk factors for stroke. Although it is difficult to compare these rates directly because of difference in study populations and methodologies, awareness, treatment, and control rates of traditional risk factors for stroke seemed to have increased in many East Asian countries (Table 5). For example, rising trends for awareness rates for hypertension have been observed in the Republic of Korea (34\% in 2001 and $63.2 \%$ in 2010-2012), ${ }^{27}$ and Taiwan (about 23-39\% in 19931996 and $56-74 \%$ in 2002). ${ }^{28}$ There has also been an increase in the control rates for hypertension in Japan, the Republic of Korea, Taiwan, and China (Table 5).

In Asia, the awareness and treatment rates of vascular risk factors are higher in older populations, women, and patients living in urban areas. ${ }^{26,27,30,38,81,82}$ Increases in education level, preventive measures implemented by health professionals and the government, and campaigns and advertisements may have contributed to these improvements in awareness, treatment, and control rate of risk factors. ${ }^{83}$ However, despite the improvements, these rates, particularly the control rate, still remain low. Most regions have lower than approximately 50\% control rates. These rates are lower than those in Western countries. For example, in the United States, the awareness, treatment, and control rates of hypertension were $81 \%, 74 \%$, and $53 \%$, respectively. ${ }^{84}$ This implies that proper public health strategies and optimal treatment approaches should be adopted to further reduce stroke and cardiovascular risks. For example, innovative initiatives targeting children have shown some success. A meta-analysis of 58 studies evaluating interventions in children to increase stroke awareness indicated a 70\% improvement compared to baseline. ${ }^{85}$

Many East Asian countries have had weak national legislation prohibiting passive smoking or restricting the activities of the tobacco industry. ${ }^{62}$ In fact, the percentage of those planning to stop smoking is low $(<20 \%)$ among current Asian smokers. Support for the cessation of drug use is not enough. For example, only $5-14 \%$ of smokers use nicotine replacement drugs in East Asia. Considering the benefits of implementing multi-component quitting assistance systems on smoking cessation, ${ }^{62,86}$ more aggressive multidisciplinary tobacco control policies are needed in many East Asian countries.

\section{Limitations}

There are some limitations in this review. First, we did not include other risk factors, such as atrial fibrillation (AF), whose incidence is expected to increase in Asia. ${ }^{87}$ Second, the associations between traditional risk factors and stroke subtypes or stroke mechanisms were not reviewed in detail. In addition, other Asian regions, such as South and Southeast Asia, were not included in this review.

\section{Conclusions}

Over the past decades, Asia has experienced rapid epidemiologic transitions. Along with economic and nutritional changes, the burden of vascular risk factors and their impact on cardiovascular disease has changed in East Asian countries. Although there are some variations between countries, hypertension is still prevalent and a significant risk factor for stroke in many Asian countries. The burdens of diabetes and hypercholesterolemia will continue to increase. Asia also remains a high tobacco consuming area. Although awareness of patients' diagnoses and risk factors has improved compared to the past decades, these rates remain low. Treatment and control rates are even lower in East Asia. The incidence or burden of stroke has differentially changed in response to the burdens of risk factors in Asian countries. These imply that further efforts will be required to determine the exact epidemiologic statuses and to plan interventional ap- 
proaches for reducing the burdens of risk factors and stroke in East Asia.

\section{References}

1. Murray CJL, Vos T, Lozano R, Naghavi M, Flaxman AD, Michaud C, et al. Disability-adjusted life years (DALYs) for 291 diseases and injuries in 21 regions, 1990-2010: a systematic analysis for the Global Burden of Disease Study 2010. Lancet 2012;380:2197-2223.

2. World Health Organization. WHO Health statistics and information systems. http://www.who.int/healthinfo/global_burden_disease/en/ (assessed Aug 10, 2015).

3. Feigin VL, Lawes CM, Bennett DA, Barker-Collo SL, Parag V. Worldwide stroke incidence and early case fatality reported in 56 population-based studies: a systematic review. Lancet Neurol 2009;8:355-369.

4. Krishnamurthi RV, Feigin VL, Forouzanfar MH, Mensah GA, Connor M, Bennett DA, et al. Global and regional burden of first-ever ischaemic and haemorrhagic stroke during 19902010: findings from the Global Burden of Disease Study 2010. Lancet Glob Health 2013;1:e259-281.

5. Ueshima H, Sekikawa A, Miura K, Turin TC, Takashima N, Kita $Y$, et al. Cardiovascular disease and risk factors in Asia: a selected review. Circulation 2008;118:2702-2709.

6. Mehndiratta MM, Khan M, Mehndiratta P, Wasay M. Stroke in Asia: geographical variations and temporal trends. J Neurol Neurosurg Psychiatry 2014;85:1308-1312.

7. Enkh-Oyun T, Kotani K, Davaalkham D, Uehara R, Sadakane A, Aoyama $Y$, et al. Hypertension in Mongolia: an overview. Ethn Dis 2013;23:363-368.

8. Choi YJ, Cho YM, Park CK, Jang HC, Park KS, Kim SY, et al. Rapidly increasing diabetes-related mortality with socio-environmental changes in South Korea during the last two decades. Diabetes Res Clin Pract 2006;74:295-300.

9. Kim S, Moon S, Popkin BM. The nutrition transition in South Korea. Am J Clin Nutr 2000;71:44-53.

10. Okayama A, Ueshima $H$, Marmot MG, Nakamura M, Kita $Y$, Yamakawa M. Changes in total serum cholesterol and other risk factors for cardiovascular disease in Japan, 1980-1989. Int J Epidemiol 1993;22:1038-1047.

11. Shintani $\Pi$, Hughes CK. Traditional diets of the Pacific and coronary heart disease. J Cardiovasc Risk 1994;1:16-20.

12. Ma RC, Chan JC. Type 2 diabetes in East Asians: Similarities and differences with populations in Europe and the United States. Ann N Y Acad Sci 2013;1281:64-91.

13. Yoon $\mathrm{KH}$, Lee JH, Kim JW, Cho JH, Choi YH, Ko SH, et al. Epidemic obesity and type 2 diabetes in Asia. Lancet 2006;368:
1681-1688

14. Wang L, Kong L, Wu F, Bai Y, Burton R. Preventing chronic diseases in China. Lancet 2005;366:1821-1824.

15. Chan JC, Malik V, Jia W, Kadowaki T, Yajnik CS, Yoon KH, et al. Diabetes in Asia: epidemiology, risk factors, and pathophysiology. JAMA 2009;301:2129-2140.

16. Woodward M, Huxley $R$, Ueshima $H$, Fang $X$, Kim HC, Lam TH. The Asia Pacific Cohort Studies Collaboration: a decade of achievements. Global Heart 2012;7:343-351.

17. Khan NA, Quan H, Hill MD, Pilote L, McAlister FA, Palepu A, et al. Risk factors, quality of care and prognosis in South Asian, East Asian and White patients with stroke. BMC Neurol 2013; $13: 74$

18. Danaei G, Finucane MM, Lin JK, Singh GM, Paciorek CJ, Cowan $\mathrm{MJ}$, et al. National, regional, and global trends in systolic blood pressure since 1980: systematic analysis of health examination surveys and epidemiological studies with 786 country-years and 5.4 million participants. Lancet 2011;377: 568-577.

19. Danaei G, Finucane MM, Lu Y, Singh GM, Cowan MJ, Paciorek $\mathrm{CJ}$, et al. National, regional, and global trends in fasting plasma glucose and diabetes prevalence since 1980: systematic analysis of health examination surveys and epidemiological studies with 370 country-years and 2.7 million participants. Lancet 2011;378:31-40.

20. Farzadfar F, Finucane MM, Danaei G, Pelizzari PM, Cowan MJ, Paciorek $\mathrm{CJ}$, et al. National, regional, and global trends in serum total cholesterol since 1980: systematic analysis of health examination surveys and epidemiological studies with 321 country-years and 3.0 million participants. Lancet 2011; 377:578-586.

21. $\mathrm{Ng} M$, Freeman $M K$, Fleming TD, Robinson $M$, Dwyer-Lindgren $\mathrm{L}$, Thomson B, et al. Smoking prevalence and cigarette consumption in 187 countries, 1980-2012. JAMA 2014;311:183192.

22. Kearney PM, Whelton $M$, Reynolds $K$, Muntner $P$, Whelton PK, He J. Global burden of hypertension: analysis of worldwide data. Lancet 2005;365:217-223.

23. Lawes CM, Vander Hoorn $S$, Law MR, Elliott $P$, MacMahon $S$, Rodgers $A$. Blood pressure and the global burden of disease 2000. Part 1: Estimates of blood pressure levels. J Hypertens 2006;24:413-422.

24. Kearney PM, Whelton M, Reynolds K, Whelton PK, He J. Worldwide prevalence of hypertension: a systematic review. $J$ Hypertens 2004;22:11-19.

25. Ueshima H. Explanation for the Japanese paradox: Prevention of increase in coronary heart disease and reduction in stroke. J Atheroscler Thromb 2007;14:278-286. 
26. Miura K, Nagai M, Ohkubo T. Epidemiology of hypertension in Japan: where are we now? Circ J 2013;77:2226-2231.

27. Korea Center For Disease Control \& Prevention MoHW. Korea health statistics 2014: Korea National Health and Nutrition Examination Survey (KNHANES VI).

28. Su TC, Bai CH, Chang HY, You SL, Chien KL, Chen MF, et al. Evidence for improved control of hypertension in Taiwan: 1993-2002. J Hypertens 2008;26:600-606.

29. Wu X, Duan X, Gu D, Hao J, Tao S, Fan D. Prevalence of hypertension and its trends in Chinese populations. Int J Cardiol 1995;52:39-44.

30. Wu Y, Huxley R, Li L, Anna V, Xie G, Yao C, et al. Prevalence, awareness, treatment, and control of hypertension in China: data from the China National Nutrition and Health Survey 2002. Circulation 2008;118:2679-2686.

31. Gao Y, Chen G, Tian H, Lin L, Lu J, Weng J, et al. Prevalence of hypertension in China: a cross-sectional study. PLOS ONE 2013;8:e65938.

32. Public health institute: Mongolian STEPS survey on the prevalence of noncommunicable disease and injury risk factors2009. Ministry of health, Mongolia. 2009.

33. Public health institute: Mongolian STEPS survey on the prevalence of noncommunicable disease and injury risk factors2006. Ministry of health, Mongolia. 2006.

34. Ma YQ, Mei WH, Yin P, Yang XH, Rastegar SK, Yan JD. Prevalence of hypertension in Chinese cities: a meta-analysis of published studies. PLoS ONE 2013;8:e58302.

35. Fang L, Song J, Ma Z, Zhang L, Jing $C_{1}$ Chen D. Prevalence and characteristics of hypertension in mainland Chinese adults over decades: a systematic review. J Hum Hypertens 2014;28: 649-656.

36. Hong KS, Bang OY, Kang DW, Yu KH, Bae HJ, Lee JS, et al. Stroke statistics in Korea: Part i. Epidemiology and risk factors: a report from the Korean Stroke Society and Clinical Research Center for Stroke. J Stroke 2013;15:2-20.

37. Nguyen HN, Fujiyoshi A, Abbott RD, Miura K. Epidemiology of cardiovascular risk factors in Asian countries. Cir J 2013;77: 2851-2859.

38. Gu D, Reynolds K, Wu X, Chen J, Duan X, Muntner P, et al. Prevalence, awareness, treatment, and control of hypertension in China. Hypertension 2002;40:920-927.

39. Gregg EW, Cadwell BL, Cheng YJ, Cowie CC, Williams DE, Geiss $L$, et al. Trends in the prevalence and ratio of diagnosed to undiagnosed diabetes according to obesity levels in the U.S. Diabetes Care 2004;27:2806-2812.

40. Yang W, Lu J, Weng J, Jia W, Ji L, Xiao J, et al. Prevalence of diabetes among men and women in China. N Engl J Med 2010; 362:1090-1101.
41. $X u Y$, Wang $L$, He J, et al. Prevalence and control of diabetes in Chinese adults. JAMA 2013;310:948-959.

42. Jiang YD, Chang $\mathrm{CH}$, Tai TY, Chen JF, Chuang LM. Incidence and prevalence rates of diabetes mellitus in Taiwan: analysis of the 2000-2009 Nationwide Health Insurance database. $J$ Formos Med Assoc 2012;111:599-604.

43. Suvd J, Gerel B, Otgooloi H, Purevsuren D, Zolzaya H, Roglic $\mathrm{G}$, et al. Glucose intolerance and associated factors in Mongolia: results of a national survey. Diabet Med 2002;19:502508.

44. Guariguata L, Whiting DR, Hambleton I, Beagley J, Linnenkamp U, Shaw JE. Global estimates of diabetes prevalence for 2013 and projections for 2035. Diabetes Res Clin Pract 2014; 103:137-149.

45. Dickinson S, Colagiuri S, Faramus E, Petocz P, Brand-Miller JC. Postprandial hyperglycemia and insulin sensitivity differ among lean young adults of different ethnicities. J Nutr 2002; 132:2574-2579.

46. Li H, Oldenburg B, Chamberlain C, O'Neil A, Xue B, Jolley D, et al. Diabetes prevalence and determinants in adults in China mainland from 2000 to 2010: a systematic review. Diabetes Res Clin Pract 2012;98:226-235.

47. Yamada M, Wong FL, Kodama K, Sasaki H, Shimaoka K, Yamakido M. Longitudinal trends in total serum cholesterol levels in a Japanese cohort, 1958-1986. J Clin Epidemiol 1997; 50:425-434.

48. Li YH, Li Y, Davis CE, Chen Z, Tao S, Folsom AR, et al. Serum cholesterol changes from 1983-1984 to 1993-1994 in the People's Republic of China. Nutr Metab Cardiovasc Dis 2002; 12:118-126.

49. Jee SH, Appel ப, Suh I, Whelton PK, Kim IS. Prevalence of cardiovascular risk factors in South Korean adults: results from the Korea Medical Insurance Corporation (KMIC) study. Ann Epidemiol 1998;8:14-21.

50. Wakugami K, Iseki K, Kimura Y, Okumura K, Ikemiya Y, Muratani $H$, et al. Relationship between serum cholesterol and the risk of acute myocardial infarction in a screened cohort in Okinawa, Japan. Jpn Circ J 1998;62:7-14.

51. Chen Z, Peto R, Collins R, MacMahon S, Lu J, Li W. Serum cholesterol concentration and coronary heart disease in population with low cholesterol concentrations. BMJ 1991;303: 276-282.

52. Enkh-Oyun T, Kotani K, Swanson E. Ischemic heart disease among the general Mongolian population: a review of epidemiological studies. Int Health 2016;8:13-17.

53. Tseng $L N$, Tseng $Y H$, Jiang YD, Chang $\mathrm{CH}_{\text {, Chung }} \mathrm{CH}$, Lin $\mathrm{BJ}$, et al. Prevalence of hypertension and dyslipidemia and their associations with micro- and macrovascular diseases in patients 
with diabetes in Taiwan: an analysis of nationwide data for 2000-2009. J Formos Med Assoc 2012;111:625-636.

54. Zhou B, Rao X, Dennis BH, Li Y, Zhuo Q, Folsom AR, et al. The relationship between dietary factors and serum lipids in chinese urban and rural populations of Beijing and Guangzhou. PRC-USA Cardiovascular and Cardiopulmonary Research group. Int J Epidemiol 1995;24:528-534.

55. Popkin BM, Horton S, Kim S, Mahal A, Shuigao J. Trends in diet, nutritional status, and diet-related noncommunicable diseases in China and India: the economic costs of the nutrition transition. Nutrition Reviews 2001;59:379-390.

56. Ueshima $H$, lida $M$, Shimamoto $T$, Konishi $M$, Tanigaki $M$, Doi $M$, et al. Dietary intake and serum total cholesterol level: their relationship to different lifestyles in several Japanese populations. Circulation 1982;66:519-526.

57. Wu Y. Overweight and obesity in China: The once lean giant has a weight problem that is increasing rapidly. BMJ 2006; 333:362-363.

58. Kim DM, Ahn CW, Nam SY. Prevalence of obesity in Korea. Obes Rev 2005;6:117-121.

59. Kim HM, Park J, Kim HS, Kim DH, Park SH. Obesity and cardiovascular risk factors in Korean children and adolescents aged 10-18 years from the Korean National Health and Nutrition Examination Survey, 1998 and 2001. Am J Epidemiol 2006; 164:787-793.

60. Yatsuya $H_{1}$ Yamagishi $K_{1}$ Iso $H$. Adiposity and risk of cardiovascular diseases in Japan: secular trend, individual level associations and causal pathway - implications for the prevention of cardiovascular diseases in societies with rapid economic development. EPMA J 2011;2:65-73.

61. Li Q, Hsia J, Yang G. Prevalence of smoking in China in 2010. N Engl J Med 2011;364:2469-2470.

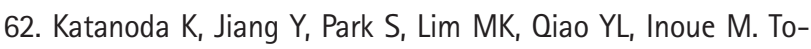
bacco control challenges in East Asia: proposals for change in the world's largest epidemic region. Tobacco Control 2014;23: 359-368.

63. Chen Z, Peto R, Zhou M, lona A, Smith M, Yang L, et al. Contrasting male and female trends in tobacco-attributed mortality in China: evidence from successive nationwide prospective cohort studies. Lancet 2015;386:1447-1456.

64. Li H, Ge J. Cardiovascular diseases in China: current status and future perspectives. IJC Heart \& Vasculature 2015;6:2531.

65. Feigin VL, Forouzanfar $M H$, Krishnamurthi $R$, Mensah GA, Connor M, Bennett DA, et al. Global and regional burden of stroke during 1990-2010: findings from the Global Burden of Disease Study 2010. Lancet 2014;383:245-254.

66. Lawes CM, Rodgers A, Bennett DA, Parag V, Suh I, Ueshima $H_{1}$ et al. Blood pressure and cardiovascular disease in the Asia Pacific region. J Hypertens 2003;21:707-716.

67. Martiniuk AL, Lee CM, Lawes CM, Ueshima $H$, Suh I, Lam TH, et al. Hypertension: its prevalence and population-attributable fraction for mortality from cardiovascular disease in the Asia-Pacific region. J Hypertens 2007;25:73-79.

68. Hyun KK, Huxley RR, Arima H, Woo J, Lam TH, Ueshima H, et al. A comparative analysis of risk factors and stroke risk for Asian and non-Asian men: the Asia Pacific Cohort Studies Collaboration. Int J Stroke 2013;8:606-611.

69. Woodward M, Huxley H, Lam TH, Barzi F, Lawes CM, Ueshima $H$, et al. A comparison of the associations between risk factors and cardiovascular disease in Asia and Australasia. Eur $J$ Cardiovasc Prev Rehabil 2005;12:484-491.

70. Perkovic V, Huxley R, Wu Y, Prabhakaran D, MacMahon S. The burden of blood pressure-related disease: a neglected priority for global health. Hypertension 2007;50:991-997.

71. Chen X, Zhou L, Zhang Y, Yi D, Liu L, Rao W, et al. Risk factors of stroke in Western and Asian countries: a systematic review and meta-analysis of prospective cohort studies BMC Public Health 2014;14:776.

72. Feigin VL, Roth GA, Naghavi M, Parmar P, Krishnamurthi $R$, Chugh $\mathrm{S}$, et al. Global burden of stroke and risk factors in 188 countries, during 1990-2013: a systematic analysis for the Global Burden of Disease Study 2013. Lancet Neurol 2016; 15:913-924.

73. O'Donnell MJ, Chin SL, Rangarajan S, Xavier D, Liu L, Zhang H, et al. Global and regional effects of potentially modifiable risk factors associated with acute stroke in 32 countries (INTERSTROKE): a case-control study. Lancet 2016;388:761-775.

74. Kubo M, Hata J, Doi Y, Tanizaki Y, lida M, Kiyohara Y. Secular trends in the incidence of and risk factors for ischemic stroke and its subtypes in Japanese population. Circulation 2008; 118:2672-2678.

75. Park TH, Ko Y, Lee SJ, Lee KB, Lee J, Han MK, et al. Identifying target risk factors using population attributable risks of ischemic stroke by age and sex. J Stroke 2015;17:302-311.

76. Jung KH, Lee SH, Kim BJ, Yu KH, Hong KS, Lee BC, et al. Secular trends in ischemic stroke characteristics in a rapidly developed country: results from the Korean Stroke Registry Study (secular trends in Korean stroke). Circ Cardiovasc Qual Outcomes 2012;5:327-334.

77. Kim YD, Choi HY, Cho HJ, Cha MJ, Nam CM, Han SW, et al. Increasing frequency and burden of cerebral artery atherosclerosis in Korean stroke patients. Yonsei Med J 2010;51:318325.

78. Uchiyama S. Impact of metabolic syndrome as a risk factor for atherothrombotic stroke. Intern Med 2005;44:1021-1022. 
79. Kim YD, Choi HY, Jung YH, Nam CM, Yang JH, Cho HJ, et al. Classic risk factors for atherosclerosis are not major determinants for location of extracranial or intracranial cerebral atherosclerosis. Neuroepidemiology 2009;32:201-207.

80. Kim JS, Nah HW, Park SM, Kim SK, Cho KH, Lee J, et al. Risk factors and stroke mechanisms in atherosclerotic stroke: intracranial compared with extracranial and anterior compared with posterior circulation disease. Stroke 2012;43:3313-3318.

81. Su TC, Bai CH, Chang HY, You SL, Chien KL, Chen MF, et al. Evidence for improved control of hypertension in Taiwan: 1993-2002. J Hypertens 2008;26:600-606.

82. Xu Y, Wang L, He J, Bi Y, Li M, Wang T. Prevalence and control of diabetes in Chinese adults. JAMA 2013;310:948-959.

83. Wu L, He Y, Jiang B, Sun D, Wang J, Liu M, et al. Trends in prevalence, awareness, treatment and control of hypertension during 2001-2010 in an urban elderly population of China. PLoS ONE 2015;10:e0132814.

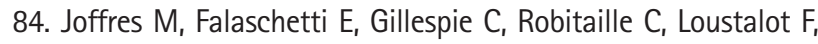
Poulter N. Hypertension prevalence, awareness, treatment and control in national surveys from England, the USA and Cana$\mathrm{da}$, and correlation with stroke and ischaemic heart disease mortality: a cross-sectional study. BMJ open 2013;3:e003423.

85. Ottawa C, Sposato LA, Nabbouh F, Saposnik G, Stroke Outcomes Research C. Stroke preparedness in children: Translating knowledge into behavioral intent: a systematic review and meta-analysis. Int J Stroke 2015;10:1008-1013.

86. Chang FC, Chung $\mathrm{CH}, \mathrm{Yu}$ PT, Chao KY. The impact of graphic cigarette warning labels and smoke-free law on health awareness and thoughts of quitting in Taiwan. Health Educ Res 2011;26:179-191.

87. Bang OY, Hong KS, Heo JH, Koo J, Kwon SU, Yu KH, et al. New oral anticoagulants may be particularly useful for Asian stroke patients. J Stroke 2014;16:73-80.

88. Goldstein LB, Bushnell CD, Adams RJ, Appel L, Braun LT, Chaturvedi $S$, et al. Guidelines for the primary prevention of stroke: a guideline for healthcare professionals from the American Heart Association/American Stroke Association. Stroke 2011; 42:517-584.

89. Ikeda N, Sapienza D, Guerrero R, Aekplakorn W, Naghavi M, Mokdad AH, et al. Control of hypertension with medication: a comparative analysis of national surveys in 20 countries. Bull World Health Organ 2014;92:10-19C.

90. Tanaka T, Okamura T, Yamagata Z, Takebayashi T, Tamura U, Kusaka Y, et al. Awareness and treatment of hypertension and hypercholesterolemia in Japanese workers: The High-Risk and Population Strategy for Occupational Health Promotion (HIPOP-OHP) study. Hypertens Res 2007;30:921-928.

91. Pan WH, Chang HY, Yeh WT, Hsiao SY, Hung YT. Prevalence, awareness, treatment and control of hypertension in Taiwan: Results of Nutrition and Health Survey in Taiwan (NAHSIT) 1993-1996. J Hum Hypertens 2001;15:793-798.

92. Yamamoto $Y$, Sonoyama K, Matsubara K, Furuse M, Yatsuhashi T, Hamada $T$, et al. The status of hypertension management in Japan in 2000. Hypertens Res 2002;25:717-725.

93. Konta $T$, Ikeda $A$, Ichikawa $K_{1}$ Fujimoto $S$, Iseki $K_{1}$ Moriyama $T$, et al. Blood pressure control in a Japanese population with chronic kidney disease: a baseline survey of a nationwide cohort. Am J Hypertens 2012;25:342-347.

94. Hu D, Fu P, Xie J, Chen CS, Yu D, Whelton PK, et al. Increasing prevalence and low awareness, treatment and control of diabetes mellitus among Chinese adults: the interASIA study. Diabetes Res Clin Pract 2008;81:250-257.

95. Pan WH, Yeh WT, Chang HY, Hwu CM, Ho LT. Prevalence and awareness of diabetes and mean fasting glucose by age, sex, and region: results from the Nutrition and Health Survey in Taiwan, 1993-1996. Diabet Med 2003;20:182-185.

96. Kobayashi M, Yamazaki K, Hirao K, Oishi M, Kanatsuka A, Yamauchi $M$, et al. The status of diabetes control and antidiabetic drug therapy in Japan--a cross-sectional survey of 17,000 patients with diabetes mellitus (JDDM 1). Diabetes Res Clin Pract 2006;73:198-204.

97. Arai K, Hirao K, Matsuba I, Takai M, Matoba K, Takeda H, et al. The status of glycemic control by general practitioners and specialists for diabetes in Japan: a cross-sectional survey of 15,652 patients with diabetes mellitus. Diabetes Res Clin Pract 2009;83:397-401.

98. Chuang LM, Tsai ST, Huang BY, Tai TY, Diabcare-Asia Study G. The status of diabetes control in Asia--a cross-sectional survey of 24317 patients with diabetes mellitus in 1998. Diabet Med 2002;19:978-985.

99. Lin SD, Tsai ST, Tu ST, Su CC, Chen JF, Lu CH, et al. Glycosylated hemoglobin level and number of oral antidiabetic drugs predict whether or not glycemic target is achieved in insulin-requiring type 2 diabetes. Prim Care Diabetes 2015;9:135-141.

100. Chien MN, Chen YL, Hung YJ, Wang SY, Lu WT, Chen CH, et al. Glycemic control and adherence to basal insulin therapy in Taiwanese patients with type 2 diabetes mellitus. J Diabetes Investig 2016. Epub ahead of print.

101. Huang Y, Gao L, Xie X, Tan SC. Epidemiology of dyslipidemia in Chinese adults: meta-analysis of prevalence, awareness, treatment, and control. Popul Health Metr 2014;12:28.

102. Takahashi E, Moriyama K, Yamakado M. Status of dyslipidemia treatment in Japanese adults: an analysis of the 2009 Japan Society of Ningen Dock database. Intern Med 2013;52: 295-301.

103. Hsuan CF, Lee TL, Chang HL, Tseng WK, Wu CC. A retrospec- 
tive study of statin use and its effectiveness in Taiwanese. Acta Cardiol Sin 2009;25:18-25.

104. Waters DD, Brotons C, Chiang CW, Ferrieres J, Foody J, Jukema JW, et al. Lipid treatment assessment project 2: a multi- national survey to evaluate the proportion of patients achieving low-density lipoprotein cholesterol goals. Circulation 2009;120:28-34. 